\title{
Strengthening of Fly Ash Bricks By Ironite
}

\author{
M.Narmatha ${ }^{1}$ R.Aruna ${ }^{2}$ M.Saraswathi ${ }^{3}$ \\ Department of Civil Engineering, Pavai College of Technology Namakkal, India \\ Department of Civil Engineering, Bharath polytechnic college, Namakkal, India
}

\begin{abstract}
This project comprises of strengthening the compressed fly ash bricks by addition of Ironite powder.The green movement has greatly influenced the design and construction of the built infrastructure across the globe. There is a growing interest in delivering high performance building systems. A highperformance building is as defined in the Energy Policy Act of 2005 [1]:a building that integrates and optimizes all major high performance building attributes, including energy efficiency, durability, life cycle performance, and occupant productivity.

This view was echoed by the US building enclosure community in 2008 when they launched a formal initiative which underscored the linkages between energy efficiency, durability and the quality of the indoor environment. The discussion in this paper focuses on the realization of high performance buildings through developing more ecological and durable walling elements based on the use of compressed fly ash bricks by adding the admixture named Ironite materials to the compressed fly ash bricks at certain ratio. In this we are going to show the improvement of strength in fly ash bricks through a comparative study.
\end{abstract}

Keywords: Fly ash, Sand/stone dust, Lime, Gypsum, Cement, Ironite.

\section{Introduction}

Fly Ash bricks are made of fly ash, lime, gypsum and sand. These can be extensively used in all building constructional activities similar to that of common burnt clay bricks. The fly ash bricks are comparatively lighter in weight and stronger than common clay bricks. Since fly ash is being accumulated as waste material in large quantity near thermal power plants and creating serious environmental pollution problems, its utilization as main raw material in the manufacture of bricks will not only create sample opportunities for its proper and useful disposal but also help in environmental pollution control to a greater extent in the surrounding areas of power plants. In view of superior quality and eco-friendly nature and government support the demand for Fly Ash Bricks About 150 million ash bricks have been manufactured and used in house consumption. All the plant use similar processes called FAL-G Technology by using fly ash, cement/lime and gypsum to manufacture fly ash bricks. These bricks are water cured, thus avoiding the need of firing or stream curing of the bricks. These Guidelines have been prepared based on inputs provided by various NTPC plants .These guideline are uniformly followed by manufacturing unit which are conformed through IS:12894.

\section{Fly Ash}

Fly ash is finely divided residue resulting from the combustion of powdered coal transported by the flue gases and collected by electrostatic precipitator. In UK it is referred as pulverized fuel ash .fly ash is the most widely used pozzalanic material all over the world. Fly Ash is the inorganic mineral residue obtained after burning of coal/lignite in the boilers. Fly Ash is the portion of ash which is collected from the hoppers of ESP's and pond ash is collected from the ash ponds. Bottom ash is the portion of ash which can be collected from the bottom portion of the boilers. The characteristics of fly ash depens upon the quality of lignite/coal and the efficiency of boilers. In general fly ash collected from $1^{\text {st }}$ or $2^{\text {nd }}$ fields of ESP's as per IS: 3812.

\section{Sand/Stone Dust}

All plants use locally available sand/stone dust which is used for collecting works. The following practice generally followed by most of the plants is recommended. Deleterious material such as clay and silt in sand /stone dust shall not be more than 5\% 


\section{Lime}

Quick Lime or hydrated lime or both can be mixed in the composition. Lime should have minimum $40 \% \mathrm{CaO}$ content. Most of the plants use sludge lime, available as waste from acctelyne industries since hydrated lime confirming much costlier than sludge lime. Use of sludge lime also gives good quality bricks. However following problems have been noticed while using sludge lime

i. The sludge lime contains extraneous material

ii. It is generally wet

iii. It contain lumps

iv. It is difficult to know the $\%$ of available lime $(\mathrm{CaO})$

Based on the experience of sites the following is recommended for use of good quality sludge lime

i. Sludge lime/hydrated lime proposed to be used during the week should be tested for calcium oxide content as per clause-9(determination of available lime as $\mathrm{CaO}$ ) of IS- 1514

ii. Sludge lime shall be free of extraneous material, lumps etc. to the extent possible

\section{Gypsum}

Hydrated calcium sulphates are called gypsum. $\left(\mathrm{CaSo}_{4} 2 \mathrm{H}_{2} \mathrm{O}\right)$. Gypsum should have minimum $35 \%$ of purity and 5 to $15 \%$ may be used. The following recommendation is made for the use of gypsum in ash brick making

i. Gypsum should be free of lumps .Lumps, if any should be screened and remainder over the screen should be crushed and re-crushed before use.

Gypsum should be tested for its purity as per IS 1288 -1982. Its purity should be above $80 \%$. However, in case of variation in purity percentage of gypsum in the mix it should be adjusted to obtain desired quality of finished bricks

\section{Cement}

Cement is generally defined as binding material .Many of the manufacturing plans has replaced sludge lime to cement because of the difficulty in the supply of quality sludge lime regularly. Ordinary Portland cement conforming to IS-269, IS-8112 or IS-12269

\section{Ironite}

Ironite is an ore taken from the iron ore .It was used in flooring so that it can withstand heavy vehicles. Now a day's Strength Increasing Admixture for Concrete, also known as Ironite-R, is used to enhance the working of concrete. The plasticizing action of Strength Increasing Admixture for Concrete helps to improve the appearance mobility and strength of the products. It can also be used for the reduction in cement without loss of strength. Further, these also have cement dispersing properties that helps in the greater utilization and hydration of cement. Also, Ironite is an acid-soluble metallic salt, which means that when it comes in contact with water or acid, it creates a liquid that imparts a permanent stain. Although this stain will not color everything and is not uniform in shade or transparency, it does provide a lovely mottled earthy brown stain to concrete. It is advisable that to perform a trial in an inconspicuous area to ensure that, the color it yields. Their current application and details are as follows.

\section{Objective}

$>$ The main objective of this project is to increase the strength of the compressed earth bricks which has been provided through modified spray testing for the assessment of erosion resistance by adding the admixture Ironite.

$>$ The main objective of manufacturing fly ash bricks is to promote ash utilization in thermal power plant through FAL-G technologies

$>$ It has an advantage of reusable property that is, when the brick gets broken it can be used for construction as there will be no level change in the strength.

$>$ The Bricks manufactured through this project will be of cost economical when compared to that of the Earthen Clay Bricks.

It has also an advantage that there is no occurrence of environmental problems due to the burning of the bricks as it doesn't involve any burning process

\section{Literature Review}

Esther Obonyo, Joseph Exelbirt and Malarvizhi Baskaran. 
Are the authors of the paper "durability of compressed earth bricks: assessing erosion resistance using modified spray testing.

The discussion in this paper is part of research directed at establishing optimal stabilization strategy for compressed bricks. The deployment context for the use of the compressed bricks was Dar es Salaam (Tanzania) where manually fabricated bricks are increasingly being used in low cost housing units. This discussion specifically focuses on strategies that can be used to counter deterioration due to wind-driven rain erosion. The impact of using cement, lime, fibre and a commercial stabilizing fluid was assessed. Factory-produced bricks were used for benchmarking. The durability of the bricks was assessed using the - modified Bulletin 5 Spray Test. The different brick specimens were sprayed with water at 2.07 MPa and 4.14 MPa over one-hour time period while measuring the depth of erosion every 15 minutes. Factory-produced bricks hardly eroded at both 2.07 MPa and 4.14 MPa pressure levels. The maximum depth of erosion for Soil-Cement bricks ranged from a maximum of $0.5 \mathrm{~mm}$ at $2.07 \mathrm{MPa}$ water pressure to $0.8 \mathrm{~mm}$ at $4.14 \mathrm{MPa}$. The maximum and minimum depths of erosion for Soil-Cement-Lime bricks were $25 \mathrm{~mm}$ and $17 \mathrm{~mm}$ respectively. The inclusion of natural fibre in the bricks resulted in a sharp increase of the erosion depth to a maximum of $40 \mathrm{~mm}$ at $2.07 \mathrm{MPa}$ and $55 \mathrm{~mm}$ at 4.14 Mpa. As the use of natural fibres and lime enhances some physical-mechanical properties, further research is necessary to determine the ways for achieving this goal while maintaining acceptable levels of erosion resistance.

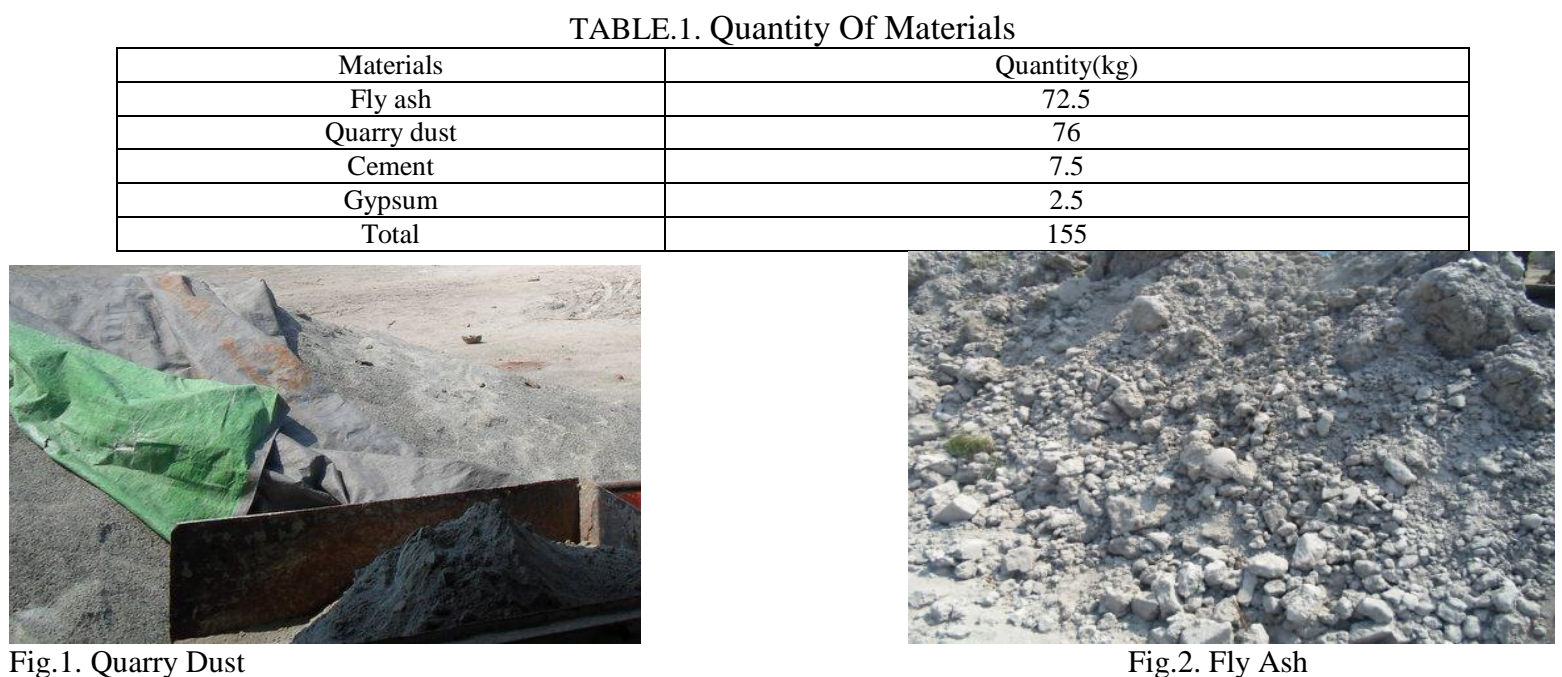

III. Machineries Used In Manufacture

$>$ Hydraulic pressure machine.

- $\quad$ Mixing Barrel

- $\quad$ Brick mould

- $\quad$ Pressure applying machine.

$>$ Planck.

$>$ Planck lifter.

The pictures of the machine and its components are shown below...

\section{Hydraulic Pressure Machine}

It is hydraulically operated automatic machine. The structure is capable of handling load up to 100 bars. Different size of mould can be fitted with machine. Embossing on brick is easy. It gives high production at minimal power loads. Circulated water cooling ensures longer operation

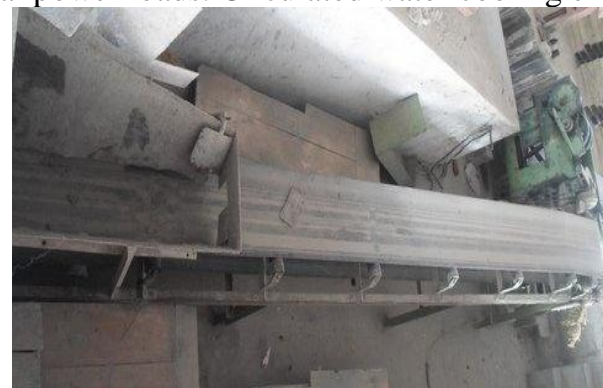

Fig.3. Hydraulic Pressure Machine

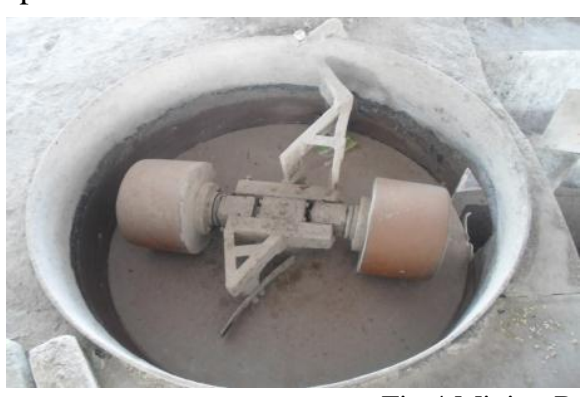

Fig.4 Mixing Barrel. 


\section{Mixing Barrel}

- A mechanical sturdy constructed with heavy rollers to grind the raw materials efficiently, Drive by worm reduction gear box.

Easy unloading mechanism with proper door arrangements

\section{Brick Mould And Pressure Allying Machine}

- The trolley capable of transporting maximum bricks to stocking area operated hydraulically, which reduces the manpower and cracks of bricks

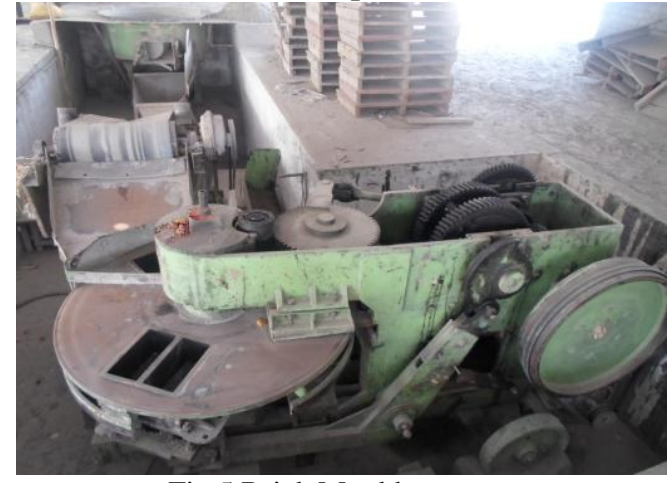

Fig.5 Brick Mould

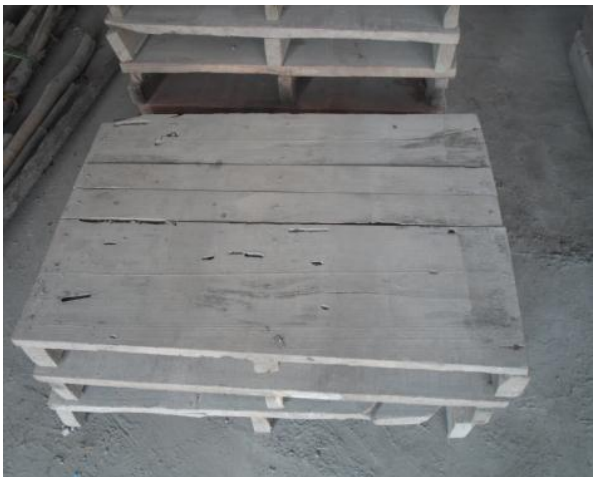

Fig.6 Plancks

A fabricated belt conveyer issued to take the raw materials of 1.5 times more than the capacity of machines. The raw materials can be regulated according to the requirements. Rubber with nylon coated belts

\section{Plancks}

- Planck is the wooden made material which is as shown in the following figure 6.

These are usually used in order to place the moulded brick over it for the further process such as air drying process.

\section{Manufacturing Process}

- The manufacturing process of brick requires fly ash, sand/stone dust, lime and gypsum to be mixed in a suitable proportion.

- $\quad$ Lime and gypsum are first added to the hydraulic mixer machine where it is ground finely as a dry mixture.

- While the mixture is mixed finely and uniformly the grinding of the machine is stopped.

- After the above process, the materials ash and the sand stone are of taken in the required quantity.

- Ash and sand /stone dust are then added into the pan -mixture to form uniform mixture.

- When cement is used in place of lime, first fly ash and sand/stone dust is mixed in pan-mixture and then cement is added into pan-mixture to have uniform dry mixture

- Now the mixer machine is made in ON condition and the above mixture is ground uniformly in the dry condition.

After this Water is added into the pan-mixture once the uniform dry mixture of fly ash, sand/stone dust and cement is achieved.

- The water content must be added in a required quantity as the mixture must be in a concentration that they must be capable of molded into the brick.

- It is to be carefully noted that the quantity of water must not be more and for per $\mathrm{Kg}$ of cement the water content ratio must not exceed $0.6 \%$.

- After the above procedure, now the Ironite material is added in order to improve the strength of the brick.

In this, ironite are added in an increasing ratio to the pan -mixture

- When the quantity of the materials are less they are needed to be transferred through the workers.

- When the quantity of the mixture is more, then the process of transferring to the mould could be done by a belt conveyor.

- Hydraulic machine consists of three pairs of brick mould.

After the quantity of the mixture content is transferred to the place of the location of brick mould, it is needed to be filled into the holes provided in the machine which represents the brick mould.

- The mould is usually provided at the circular table which is capable of rotating in clockwise direction. 
- After the mould is filled with the materials, the table is allowed to rotate in clockwise direction and then it remains under the part of closed portion of the machine.

At that portion the mixture is hydraulically pressed to obtain bricks and then the pressed bricks are pushed outside the brick mould automatically.

Once bricks are taken out from the mould, they are transferred to the Planck

- The transferring of the bricks must be carried out carefully as it is possible to get broken due to the pressure applied over it.

- When the certain ratios of the bricks are completed for the purpose of reference they are to be noted over the brick.

- When the Planck is filled by the bricks then they are to be taken by the Planck lifter for the purpose of air drying process where the bricks are air dried for 2 to 3 days.

- Water curing is done for required days and to achieve the required strength.

TABLE.2. Ironite content

\begin{tabular}{|c|c|c|c|c|}
\hline $\begin{array}{c}\text { Total weight of } \\
\text { sample (kg) }\end{array}$ & $\begin{array}{c}\text { Number of } \\
\text { bricks }\end{array}$ & $\begin{array}{c}\text { Weight of each } \\
\text { sample(kg) }\end{array}$ & $\begin{array}{c}\text { Weight of remaining } \\
\text { sample(kg) }\end{array}$ & Ironite ratio(kg) \\
\hline 155 & 5 & 16 & 138.5 & \\
\hline 138.5 & 5 & 16 & 122.5 & 1.385 \\
\hline 122.5 & 5 & 16 & 106.5 & 1.225 \\
\hline 106.5 & 5 & 16 & 90 & 1.065 \\
\hline 90 & 5 & 74 & 74 & 0.90 \\
\hline 74 & 5 & 16 & 58 & 0.74 \\
\hline 58 & 5 & 16 & 42 & 0.58 \\
\hline 42 & 5 & 16 & 26 & 0.42 \\
\hline 26 & 5 & 16 & 10 & 0.26 \\
\hline 10 & 5 & 16 & & 0.10 \\
\hline
\end{tabular}

Total ironite content added $=6.675$

TABLE.3 Testing Of Bricks

\begin{tabular}{|c|c|c|c|c|c|}
\hline S.No & Specimen & $\begin{array}{c}\text { Dimension } \\
(\mathbf{m m}) * 10\end{array}$ & $\begin{array}{c}\text { Area } \\
\left(\mathrm{mm}^{2}\right)^{* 10^{2}} \\
\end{array}$ & $\begin{array}{l}\text { Ultimate } \\
\operatorname{load}(k N)\end{array}$ & $\begin{array}{c}\text { Ultimate compressive } \\
\text { strength }\left(\mathrm{N} / \mathrm{mm}^{2}\right)\end{array}$ \\
\hline 1 & Zero & $225 * 105$ & 23625 & 240 & 10.16 \\
\hline 2 & One & $225 * 105$ & 23625 & 225 & 9.52 \\
\hline 3 & Two & $225 * 105$ & 23625 & 210 & 8.89 \\
\hline 4 & Three & $225 * 105$ & 23625 & 170 & 7.20 \\
\hline 5 & Four & $225 * 105$ & 23625 & 300 & 12.70 \\
\hline 6 & Five & $225 * 105$ & 23625 & 205 & 8.68 \\
\hline 7 & Six & $225 * 105$ & 23625 & 240 & 10.16 \\
\hline 8 & Seven & $225 * 105$ & 23625 & 235 & 9.95 \\
\hline 9 & Eight & $225 * 105$ & 23625 & 260 & 11.01 \\
\hline
\end{tabular}

\section{Result of Bricks}

The ultimate crushing strength of bricks is given by a comparative study as follows.

- The compressive strength of the zeroth specimen - normal fly ash brick is $10.16 \mathrm{MPa}$

$>$ The compressive strength of bricks after addition of ironite is as follows

$>$ For Fourth specimen $\quad=12.70 \mathrm{MPa}$

$>$ For Eighth specimen $\quad=11.01 \mathrm{MPa}$

Thus from above we are clear that the strengthening of fly ash bricks is achieved.

TABLE.4. Water Absorption Test

\begin{tabular}{|c|c|c|c|c|}
\hline S.No & Specimen & $\begin{array}{l}\text { Weight of dry bricks } \\
\left(w_{1}\right) g\end{array}$ & $\begin{array}{c}\text { Weight of brick after } \\
\text { immersing in water }\left(W_{2}\right)\end{array}$ & $\begin{array}{c}\text { Percentage of water } \\
\text { absorption }(\%)\end{array}$ \\
\hline 1 & Zero & 3391 & 3652 & 7.6 \\
\hline 2 & One & 3462 & 3716 & 7.3 \\
\hline 3 & Two & 3316 & 3595 & 8.4 \\
\hline 4 & Three & 3540 & 3800 & 7.3 \\
\hline 5 & Four & 3395 & 3636 & 7 \\
\hline 6 & Five & 3396 & 3567 & 5 \\
\hline 7 & Six & 3619 & 3859 & 6.6 \\
\hline 8 & Seven & 3506 & 3764 & 7.4 \\
\hline 9 & Eight & 3695 & 3950 & 6.9 \\
\hline
\end{tabular}




\section{Result of Water Absorption Test}

- Water absorption of the zeroth specimen $\quad=7.6 \%$

- Water absorption of the average given ironite bricks $=7 \%$

VI. Approximate Of Cost

\begin{tabular}{|c|c|c|c|c|c|}
\hline Item no & $\begin{array}{c}\text { Particular of items of } \\
\text { works }\end{array}$ & Quantity & Unit & Rate & Amount \\
\hline 1. & Fly Ash & 1612 & $\mathrm{Kg}$ & 0.35 & 564.2 \\
\hline 2. & Quarry Dust & 1689 & $\mathrm{Kg}$ & 0.46 & 776.94 \\
\hline 3. & Cement & 167 & $\mathrm{Kg}$ & 5.80 & 968.6 \\
\hline 4. & Gypsum & 56 & $\mathrm{Kg}$ & 14 & 784 \\
\hline 5. & ironite & 149 & $\mathrm{Kg}$ & 15 & 2235 \\
\hline & & & & TOTAl & 5328.74 \\
\hline
\end{tabular}

Add $5 \%$ for labour and water

Rs5595.177

Therefore for one brick the rate will be as follows,

$$
\begin{aligned}
& =\frac{5595.177}{1000} \\
& =\quad \text { Rs.5.59= Rs.6 }
\end{aligned}
$$

\section{Conclusion}

We have completed our project "Strengthening of Fly ash Bricks by Ironite" successfully. The main objective of our project is to manufacture the brick with erosion resistance. We also came to know about the material used, manufacturing method and the strength of the bricks.

From the above we came to know about the realization of high performance buildings through developing more ecological and durable walling elements based on the use of compressed fly ash bricks by adding the admixture named Ironite materials to the compressed fly ash bricks at certain ratio.

We have shown the Results over the strengthening of fly ash bricks through a comparative study between the normal Fly ash bricks and the bricks with the addition of the Admixture named Ironite. The project can be used to construct structure with erosion resistance by using these bricks.

\section{References}

[1] The manufacturing of fly ash bricks is referred from Indian standard "IS: 12894"

[2] The fly ash bricks is referred from Indian standard "IS: 3812"

[3] The lime is of from reference Indian standard "IS-1514"

[4] The gypsum is of from reference Indian standard "IS 1288-1982"

[5] The cement is of referred from Indian standard "IS-269, IS-8112 or IS-12269"

[6] "Guidelines For Manufacturing Quality Fly Ash Bricks"

[7] "Durability of compressed earth bricks: assessing erosion resistance using the modified spray testing" 